\title{
PŘÍSPĚVEK K DATOVÁNÍ ZRCADLOVÝCH KACHLŮ
}

\author{
MARKÉTA TYMONOVÁ
}

\begin{abstract}
Abstrakt: Článek se v souvislosti s datováním zrcadlových kachli̊ zabývá analýzou nálezů ze šlechtického sídla Vikštejna na Opavsku, které byly chronologicky zařazeny prostrednictvím heraldicky zdobených fragmentů s aliančními znaky Adama Oderského z Lidéř́ova a Barbary z Herbersteinu. Kamna, v nichž byly sledované kusy zabudovány, byla vyrobena v opavské hrnčiřské dílně v Jaktařském predměstí jako speciální kamnářská zakázka realizovaná v rámci stavebních úprav sídla po roce 1600.
\end{abstract}

Kličová slova: Vikštejn na Opavsku - zrcadlové kachle - alianční znak-opavská hrnčǐrská dílna - raný novověk.

\section{A Contribution to the Dating of Mirror Tiles}

Abstract: This article examines, in relation to the dating of mirror tiles, the finds from the aristocratic seat of Vikštejn in the Opava region. The tiles were dated on the basis of fragments decorated with heraldic symbols of Adam Oderský of Lidérov and Barbara of Herberstein. The stove that originally contained the tiles was made in a pottery workshop in the Jaktařské predméstí suburb in Opava, as a special commission executed within the building modifications to the residence after 1600.

Key words: Vikštejn in the Opava region-mirror tiles-alliance symbol-Opava pottery workshop-early modern age.

\section{Úvod}

Kamnářské výrobky, jejichž čelní plochy s prohloubeným středovým polem připomínají gotické nikové tvary, nedisponují tak bohatou reliéfní výzdobou, jež by umožnila s přihlédnutím k nálezovým okolnostem a ikonografické analýze slohových, genealogických, heraldických nebo historických aspektů nastínit bližší časové zařazení. Je sice pravda, že redukce figurálních či jiných interpretačně uchopitelných prvků do jisté míry omezuje výpovědní hodnotu kachlového materiálu, ale ve výjimečných případech lze $\mathrm{k}$ upřesnění doby vzniku využít nálezové celky, $\mathrm{v}$ nichž byly zrcadlové reliéfy kombinovány s heraldickou výzdobou. Při tom se v těchto případech můžeme opř́it o dobové reálie v souvztažnosti s výsledky stavebně-historických průzkumů, což zpravidla umožňuje materiál získaný z panských sídel nebo lokalit klášterního a výjimečně městského typu. Jejich historii lze poměrně přesně rekonstruovat pomocí písemných pramenů skýtajících podklady pro rodové a heraldické vývody. Tento postup můžeme aplikovat u kachlových souborů ze zaniklého Vikštejna na Opavsku (k. ú. Radkov-Dubová), jehož interiéry na počátku 17. století vytápělo několik různě glazovaných kamnových těles složených ze zrcadlových a heraldicky zdobených kachlů s letopočtem a personálními inskripcemi majitelů.

\section{Geneze a rozšíření zrcadlových kachlů}

Kamnářské výrobky s dovnitř zešikmenými diagonálními plochami a rovnou středovou plochou se v kachlové produkci objevily poměrně brzy, a to již v závěru přechodného pozdně gotického období, na což poukazuje ikonografie vnitřního interiérového vybavení z doby před polovinou 16. věku s pecemi složenými z geometricky uspořádaných kachlů (Sachs 1976, 225; Majewski 2015, 215). Kromě obrazových dokladů se při hledání počátku výskytu zrcadlových tvarů můžeme opřít také o samotný materiál, speciálně o jedince s poloválcovými komorami, zabudovávanými do nástavcové části kamen. Toto archaické konstrukční řešení přežívající v kachlové matérii ještě na počátku novověku dokládá nález ze zasypaného př́kopu frýdeckého zámku (Tymonová 2011, 85, Tab. 51/8; 2016, 425-426, obr. 9:1) nebo exemplář z deponie vyhozené do jámy v centru Bulhar u Mikulova (obr. 1; Pavlík-Šedo 2006, 23, 39-40). Její keramický obsah z doby kolem roku 1500 je spojován s předhabánskou domácí produkcí nedalekých Ivančic (obr. 1; Pavlík-Šedo 2006, 18, 23, 39-40, 44). V obou př́ípadech se jednalo o obdélné formáty 


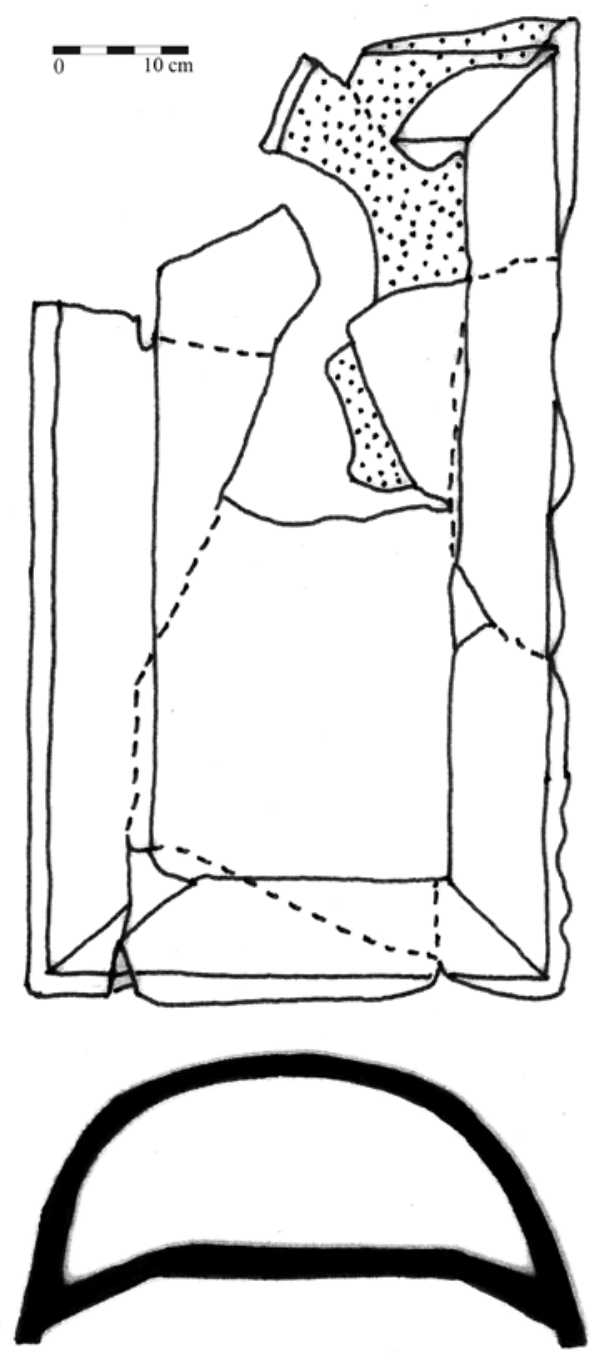

Obr. 1. Bulhary, intravilán obce. Zrcadlový kachel obdélného formátu s hladkým středovým polem a poloválcovou komorou. Podle Pavlík-Šedo 2006, 23.

Abb. 1. Bulhary, Innenbereich der Gemeinde. Spiegelkachel von rechteckigem Format mit glattem Mittelfeld und halbzylinderförmigem Hals. Nach Pavlík-Šedo 2006, 23. s režným povrchem, které svým vzhledem konvenovaly nastupující renesanční architektuře s geometricky členěnými sgrafitovými fasádami a kazetovým obložením stropů a stěn (Pavlík-Vitanovský 2004, 173-174).

Vedle obdélných formátů se $\mathrm{v}$ průběhu 16. století začaly vyrábět $i$ čtvercové tvary se snižující se kuželovou komorou, kterou po polovině 16 . století vystrídalo jednoduché pásové orámování. Nálezy známe nejen z Frýdku, odkud pochází též kusy s hladkými i zdobenými vnitřními plochami, ale rovněž z moravského hradu Rožnova (Holoubková 2013, 54-55, 128, obr. 79), české Lipnice (Pavlík-Vitanovský 2004, 304, 430, kat. č. 1206; Suchnová 2012, 30) a Rýzmburku (Hazlbauer-Hlaváček 1997, 132, tab. 2; 3:3), slovenského Kežmaroku (Polla 1970, 132, obr. 2:11; 3:8), polského Bolesławce nad Prosnou (Żemigała 1987, IV:10) a mad'arského Budína či Köszegu (Holl 1993, obr. 20-21, 23). Čtvercové a obdélné kusy se našly i v hornoslezské Opoli (Dymek 1995, 39, 269, tab. XXXILb) nebo západopomořanském Štětíně, Stargardu, Kamieniu Pomorském, Starem Drawsku, Dobrej nebo Bierzwniku (Majewski 2015, 214-215, 2019, ryc. V.88). Exempláře se zrcadlově zahloubenými plochami byly doloženy také na řadě míst v Praze (Malá Strana, Staré i Nové Město), kde se kromě klasických zeleně polévaných čtvercových a obdélných tvarů vyskytly i varianty s kruhovým či nikovým zahloubením nebo diamantově členěnými plochami (Brych-Stehlíková-Žegklitz 1990, 150-154, obr. 344-353; Brych 2004, 203, kat. č. 533-534). Zvláštní variantu představovaly tvary se čtyřmi zrcadly umístěnými v kvadrátech, reprezentované nálezy ze slezského Dzierżoniówa, Bolesławce nebo Racążku (Dymek 1995, 269, 281, tab. XXXILa, tab. LI, LH). Jejich domácí obdoby z Rožnova nebo Landštejna měly místo zrcadel vsazeny kazety s rostlinnými motivy (Pavlík-Vitanovský 2004, 178-179, 307, kat. č. 1239, 1244).

Hladká i zdobená zrcadla byla bohatě zastoupena především v kachlovém materiálu z Opavy, kde T. Krasnokutská na základě povrchové úpravy vydělila dva základní typy (2004, 106-10; 2005, 65-66). První, tedy starší, z druhé poloviny 16. století, byl na středové zrcadlové ploše zdoben florálními motivy, jako byl listovec nebo tulipánovité květy, a měl tvar bud' čtvercový či mírně obdélný (obr. 2; Krasnokutská 2005: Dolní náměstí č. 18, 97, Tab. 5:7; Kolářská ulice, 98, Tab. 6:3; Krnovská ulice č. 4, 119, Tab. 27:1-4; 5; náměstí Republiky č. 15, 132, Tab. 40:2, 3; Pekařská ulice č. 11, 143, 148, Tab. 51:2, 56:5), anebo výrazně obdélný (Krasnokutská 2005: ulice Beethovenova č. 1, 94, Tab. 2:3, a Krnovská č. 4, 119, Tab. 27:1-5). Obě varianty byly doloženy jak v řádkové, tak i rohové verzi. Druhý typ, tedy mladší, ze závěru 16. a počátku 


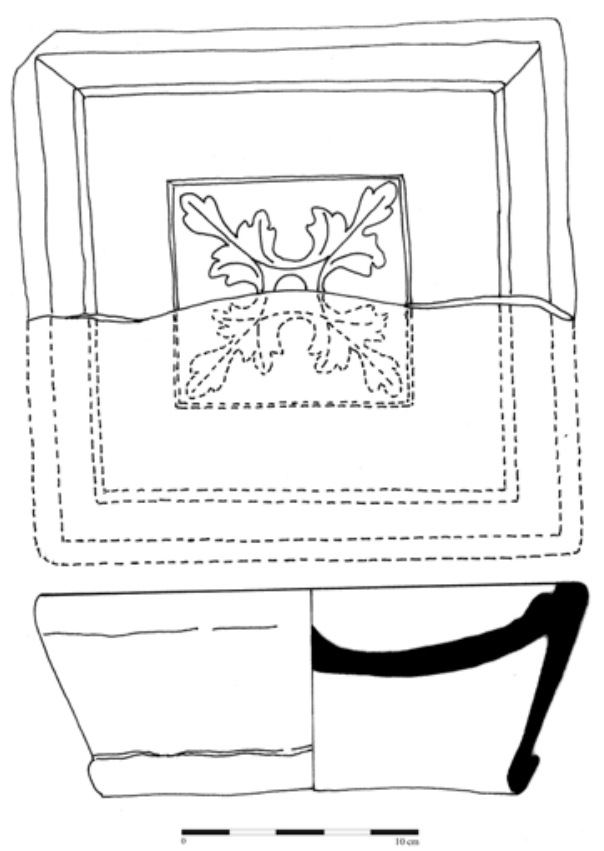

Obr. 2. Opava, náměstí Republiky. Zrcadlový kachel čtvercového formátu s listovcem v zahloubení. Podle Krasnokutská 2005, 132, Tab. 40.

Abb. 2. Opava, Platz der Republik. Spiegelkachel von quadratischem Format mit Blattwerk in der Vertiefung. Nach Krasnokutská 2005, 132, Taf. 40. věku následujícího, měl povrch zcela hladký, nezdobený, překrytý různými odstíny zelené a od počátku 17. století i tmavě hnědé glazury (Krasnokutská 2005: ulice Mnišská, 127, Tab. 35:1-2, a Pekařská č. 11, 145, 147, Tab. 53:8, 55:8). Z mimoopavských nálezů do druhé poloviny 16. století můžeme zahrnout ještě zeleně polévané kusy z Hradce Králové (PavlíkVitanovský 2004, 304, 430, kat. č. 1205) a do počátku 17. století čtvercové i obdélné kusy z Moravského Krumlova (obr. 3; Malík-Peška 1994, 103, 106, obr. 7:1-3).

$\mathrm{V}$ průběhu 16. století, kdy došlo $\mathrm{k}$ postupnému rozšíření zrcadlových kachlů, byly dekorativní trendy v domácí výrobě ovlivněny produkcí dílen provozovaných mezi lety 1526-1622 moravskými novokřtěnci (habány), kteří se z náboženských důvodů vyhýbali zobrazování antropomorfních či zoomorfních námětů a místo figurální či animální výzdoby upřednostňovali stylizované geometricko-rostlinné motivy (Pajer 2002, 182). Cizí vzory stylově čerpající z pozdně renesančních prvků se postupem času vyprofilovaly do dvou výtvarných principů. První směr prolamoval čelní stěnu kachle jednou nebo několika kruhovými miskami, transformovanými posléze v oválné nebo pravoúhlé zahloubení, jak na to poukazují kachlové kusy uložené v muzeích v Sušici, na Pražském hradě, Javorníku a mnoha dalších místech (Pavlík-Vitanovský 2004, 177, 305, kat. č. 1214-1215; Tymonová 2015, tam další literatura). Druhý výzdobný styl pokryl stěny kamen mozaikovými vzory sestavovanými do nekonečných „tapetových“ ornamentů, které vytvářely geometrizované motivy kombinované s rostlinnými prvky (Pajer 2006a, 88-89). Ty byly během druhé poloviny 16 . století vystřídány celoplošnými, kazetově uspořádanými sestavami s páskami i bez nich, doloženými nálezy ze Strážnice a také z Brna, Janovic u Rýmařova, Třebovětic a jiných míst (Pajer 1983, 117-118, obr. 58:2, 59; Dymek 1995, 39; Pavlík-Vitanovský 2004, 308, 434, kat. č. 1255-1256; Loskotová 2008, 142, 154, kat. č. 509; Goš-Karel 2011, 77, tab. 8:1).

V poslední třetině 16 . a na počátku následujícího věku byly v severní Evropě populární kachle kvadratických forem s centrálním kosočtvercem vyplněným rozetkou nebo jiným florálním prvkem, který v případě, že zůstal prázdný, vytvořil rombické zrcadlové zahloubení příznačné pro nálezy z prrímořské části Německa (Wismar, Rostock, Stralsund). V západním Pomořansku, kde se dané tvary také vyskytly (Štětín, Stargard), byly datovány do doby kolem roku 1600 (Hoffmann 2005, 64, Abb. 69; Ansorge-Schäfer 2009, 157-158, Abb. 16:a-d; Majewski 2015, 214, ryc. V.87). Tato zvláštní skupina charakterizovaná rombickým zrcadlem představovala specifický kachlový typ, který u nás zatím nemá přímé obdoby.

Geometrizace vrcholně renesanční výzdoby na kachlích vyráběných novokřtěnci i těch, které „originály“ později kopírovaly, přinášela nové inspirační impulzy, které obohatily domácí produkci nejen po stránce estetické, promítající se v „moderním“ vzhledu kamen, ale především po stránce technické a technologické. Z funkčního hlediska kachle s nižší komorou a kvadraticky rozšířeným vyhřívacím otvorem umožňovaly dosažení vyšší výhřevnosti při nižší spotřebě paliva. Z výrobního nebyly zanedbatelné ani menší nároky na množství použité kamnářské hlíny, kterou hrnčíríi specializovaní na výrobu kachlů museli velice často kupovat. Technologickou 


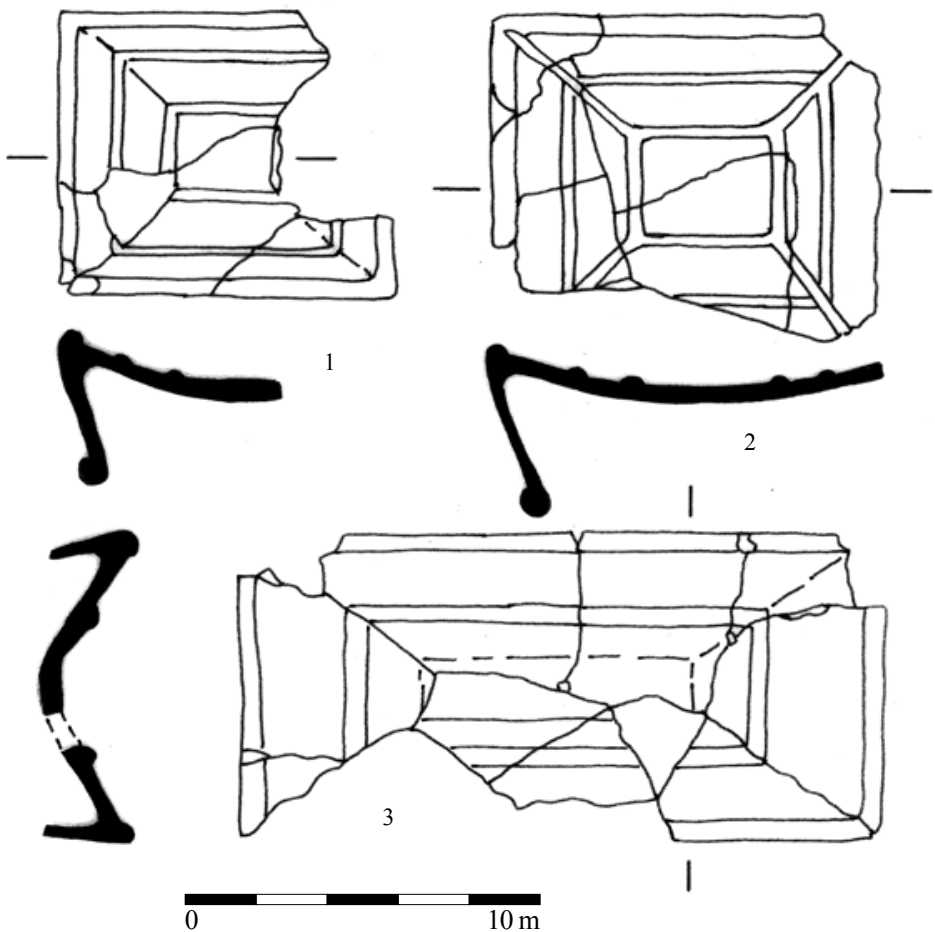

Obr. 3. Moravský Krumlov, Palackého ulice. Zrcadlové kachle s hladkým ětvercovým a obdélným zahloubením. Podle Malík-Peška 1994, 106, obr. 7:1-3.

Abb. 3. Moravský Krumlov, Palackého-Straße. Spiegelkacheln mit glatter quadratischer und rechteckiger Vertiefung. Nach Malík-Peška 1994, 106, Abb. 7:1-3.

progresi zcela jistě přineslo formování v jednotných matricích, jež výrazně zjednodušilo výrobní proces a předešlo komplikacím s výměnou vadných kusů (Hazlbauer 2003, 159-165; Preusz 2011, 77). Komplexní př́nos těchto inovací se promítal nejen v efektivitě výroby, provozu i údržby, ale i v distribuci hotového zboží, což zaprríčinilo rychlou recepci novokřtěnských kamnářských výrobků. Jejich šíření nevyvolala pouze móda, nýbrž hlavně tyto technologické aspekty, které po polovině 16 . století vedly k napodobování medailonových a mozaikových kachlů v lokálních hrnčířských dílnách (Pajer 1983, 103; Divileková 2007, 222; Tymonová 2015, 948-951; 2016, 427-428; Hlubek 2017 - článek o kachlích z Litovle uveřejněný v tomto sborníku).

Původní novokřtěnskou produkci máme doloženu především na jižní Moravě v Dambořicích (Landsfeld 1953, 208; 1974, 84; Pajer 2006a, 136; Bartošková 2008, 36-37; Sed’ová 2011, 20), Ostrožské Nové Vsi (Landsfeld 1950, 244-249; Pajer 2006a, 108-111), Staré Břeclavi (Pajer 1998, 56; 2006a, 92-93), Podivíně (Landsfeld 1947, 233-235; Pajer 1997, 188-192), Strachotíně (Pajer 1998, 190-191; 1990, 188-192, 198-199; 2001, 11; 2006a, 15, 88-90; Kalinová 2016, 275), Vacenovicích (Pajer 1999, 33; 2006a, 120-122; 2010, 499; 2011, 3) a také v menších výrobních centrech jako Kobylí, Pouzdřany, Tavíkovice, Žádovice aj. (Pajer 2006, 125-128; 2010, 507; 2011, 4; Koucká 2015, 47). Z nich se kachlové a ostatní keramické výrobky importovaly do Mikulova (Rigasová 2014, 34), Ivančic (Šebela-Vaněk 1985, 23), Strážnice (Pajer 1983, 103-117; 2002, 182-185), Čermákovic (Pajer 2015, 53) nebo Brna, kde byl zatím zjištěn jediný „originál““ (Holub-Jordánková-Loskotová 2009, 3-4, Fig. 3). 
I když zrcadlové tvary svým vzhledem ideově zapadaly do konceptu habánské ornamentiky, v publikovaných souborech schází, protože novokřtěnci dávali přednost svým vlastním dekorům a tradičně setrvávali u miskovitých a mozaikových vzorů. Z florálních měli v oblibě kupříkladu tulipánovité květy s listovím, aplikované na fajánsích, které domácí hrnčiři ve stylizované podobě přenesli na zahloubené plochy zrcadlových kachlů. $O$ jejich aplikaci svědčí výzdoba na keramice vyzvednuté ze studny v bývalém bratrském sboru v Ivančicích (ŠebelaVaněk 1985, Tab. 32:5; Krasnokutská 2005, 16), anebo na kachlovém materiálu z Opavy, odkud se kamnářská keramika rozvážela do širokého okolí. Mimo jiné i na dvě desítky kilometrů vzdálený Vikštejn, v jehož nálezovém souboru se nachází fragmenty z několika renesančních kamen složených z mozaikových, miskových a také zrcadlových kachlů, jejichž datování upřesňuje analýza heraldické výzdoby s aliančním znakem Adama Oderského z Lidéřova a Barbary z Herbersteinu související se stavebními úpravami sídla spojenými s vybavováním vnitřních interiérů u př́ležitosti jejich sňatku.

\section{Historie a archeologický výzkum hradu Vikštejna}

Zřícenina hradu zbudovaného na ostrožně obtékané řekou Moravicí k ochraně jižní části Opavského knížectví leží přibližně 5 km severně od Vítkova (obr. 4). I když se jeho výstavba předpokládá již ve druhé čtvrtině 14. století, poprvé byl zmíněn až v roce 1377, kdy připadl spolu se zmíněným městečkem a dalšími vesnicemi k dílu knížat Václava a Přemka († 1433). Po

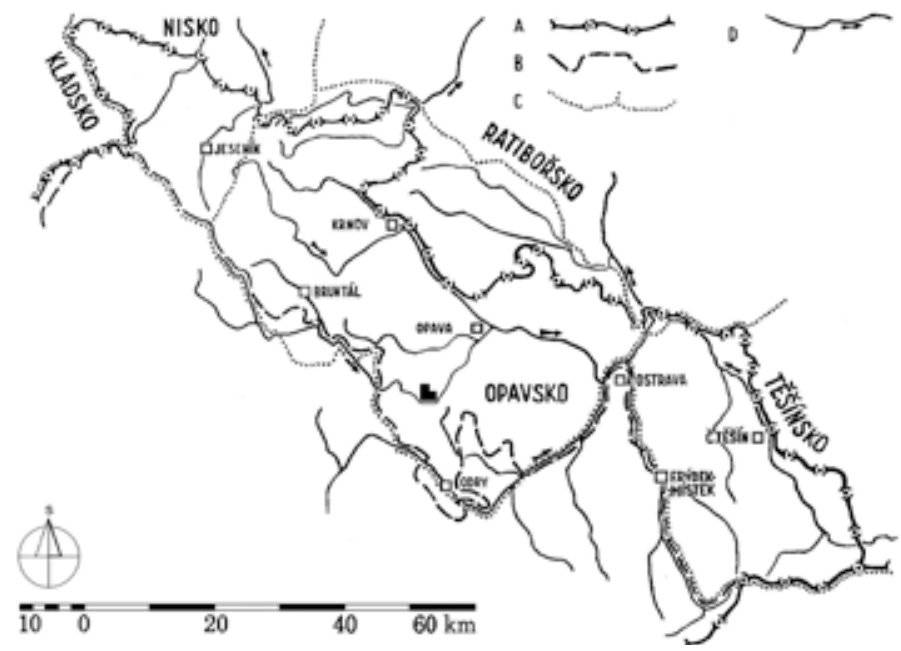

Obr. 4. Mapa českého Slezska s vyznačením polohy vikštejnského sídla. A - dnešní hranice; B - historická hranice Čech; C - hranice stř̌edověkých knížectví; D - vodní toky. Podle Kouřil-Prix-Wihoda 2000, 15 (upraveno).

Abb. 4 Karte von Tschechisch-Schlesien mit eingezeichneter Lage der Residenz Vikštejn. A - heutige Grenze; B - historische Grenze Böhmens; C - Grenze der mittelalterlichen Fürstentümer; D - Wasserläufe. Nach Kouřil-Prix-Wihoda 2000, 15 (modifiziert).

Přemkově smrti, kdy bylo Opavsko znovu rozděleno, příslušné statky přešly na Viléma a jeho bratra Arnošta, od něhož v roce 1461 hrad získal výbojný rytíř Budivoj z Moravice (KouřilPrix-Wihoda 2000, 374, 495, 498; Martinek-Kravar 2001, 12-14). Původně zeměpanské zboží však dlouho nevlastnil, protože o tři léta později byl jako zemský škůdce odsouzen ke ztrátě hrdla i panství, jež mu poté, co uprchnul ze země, Jiří z Poděbrad zabavil a jako př́ímé manství svěřil svému stoupenci Bernardovi Bírkovi z Násile († 1481). Za uherských válek se hrad, který mezitím převzal syn Hynčík, stal terčem útoků vojsk Matyáše Korvína, jehož oddíly sídlo 
označené za „Raubschloss“ roku 1474 dobyly a pobořily. Navzdory panovníkově nepřízni Bírkové o vikštejnské zboží nepřišli a teprve v roce 1512, kdy rod vymřel, převedl Vladislav Jagellonský odúmrt' na Pročka Malého z Cetně, v jehož rukách zůstala až do roku 1522.

Další tři roky se držitelé často stř́idali a nakonec v roce 1525 zadluženou zástavu získal Jan Planknar z Kynšperka († 1556), po němž ji dědila vdova Magdaléna Greisenecková z Markvartovic († 1576) a její synové (Martinek-Kravar 2001, 15-16; Furmanek-Kulpa 2003, 33-43). Od roku 1558 statky spravoval nejmladší Jan, který se po matčině smrti o dědictví rozdělil se svou jedinou př́íbuznou Magdalénou Planknarovou, s níž se však od roku 1591 začal soudit kvůli odprodeji svého dílu Janu Bravantskému z Chobřan, na nějž si zištná neteř činila přednostní nárok. Ačkoli byla provdána za Adama Oderského z Lidéřova († 1618), ještě téhož roku se usmířila s jeho synem Mikulášem, tehdy spoluvlastníkem a od roku 1594 majitelem celého panství, s nímž nějaký čas pobývala na tvrzi v Bravaticích. Důvěrné styky s mladým pánem osobujícím si právo na celé panství vyvolaly ostré spory s manželem, jež opakovaně řešil opavský zemský hejtman a kvůli násilnostem na poddaných i nejvy̌šsí soud Království českého. V Praze, kde se pře řešila, byl Mikuláš dokonce uvězněn, a když odsud roku 1598 utekl, olomoucký zemský sněm jej uznal vinným a prohlásil za škůdce. Následujícího roku se již jako psanec skrýval na Vikštejně, a poté, co Opavané na jeho hlavu vypsali odměnu, uprchl do Polska spolu s Magdalénou, kterou Rudolf II. $\mathrm{v}$ roce 1600 prohlásil za bezectnou a mrtvou. Císařův verdikt ji zbavil veškerých práv a majetku, který připadl manželovi, jemuž byl do zemských desek zapsán v roce 1612. O rok později byl dokonce jmenován císařským radou a navzdory utrpěným příkořím od bývalé partnerky se znovu oženil. Ovšem kdy se tak stalo, přesně nevíme. Víme pouze to, že za manželku pojal Barbaru z Herbersteinu (*1569) ze starobylého původem štýrského rodu. Když po smrti muže ovdověla, ještě nějakou dobu se zdržovala na Vikštejně, ale nakonec se roku 1625 odstěhovala na panství v Levicích, které zakoupila od Jiřího Adama z Drahotuš. Veškerý majetek po manželovi zdědili synové Vilém Alexandr a Jiří Adam, kteří byli v roce 1629 obviněni, že Vikštejn vydali Dánům. Kvůli nařčení z vlastizrady jim bylo panství zkonfiskováno a restituováno až po třicetileté válce v roce 1657. Sídlo ovšem převzali značně zdevastované, protože v roce 1648 bylo jako důležitý strategický bod na př́ikaz císařského generála Gonzagy pobořeno, aby nepadlo do rukou Švédů (Zukal 1916, 84-87; Schittny 1984, 83; Šikulová 1973, 87; Zahnáš 1981, 2-5; Martinek-Kravar 2001, 19-28; Hudeček-Hanák-Hudeček 2002, 29; Tymonová 2011, 122-123).

Pomineme-li příležitostné vykopávky prováděné na hradě od konce 19. století, první soubor s kachlemi do sbírek Slezského zemského muzea zapsal v roce 1954 tehdejší vedoucí prehistorického oddělení L. Jisl. Další nálezy sesbírané v areálu hradu žáky internátní školy ve Velkých Heralticích předala v roce 1968 vychovatelka Jana Schneiderová a třetí konvolut obsahující materiál z navážek sklepů a povrchové sběry v roce 1972 zachránil technik tehdejšího Okresního melioračního střediska v Opavě pan Tille (Šikulová 1973, 87; Tymonová 2011, 124). Ve všech deponovaných celcích se nacházely vzájemně kompatibilní kachlové fragmenty z několika kamnových celků, které byly pravděpodobně vyrobeny v Opavě, jak na to poukazují nálezy z Krnovské ulice, kde byla v letech 1965 a 2007 zjištěna hrnčířská dílna indikovaná odpadovými deponiemi a zlomky forem (Tymonová 2014, 161-163).

\section{Zrcadlové kachle s heraldickou výzdobou}

Kamna, v nichž byly heraldicky zdobené kusy zakomponovány, byla vyrobena v několika barevně odlišených verzích z kachlů zhotovených z jemně plavené, pískem ostřené hlíny vypálené do cihlově červených až hnědavě šedých odstínů. Jejich přesné rozměry se vzhledem ke značné fragmentaci nepodařilo určit. Ze zrcadlových kachlů byly identifikovány jak nezdobené, tak i zdobené fragmenty z řádkových kusů čtvercového i obdélného formátu s profilovanými vývalkovými lištami včetně dalších zlomků z rohových, kordonových nebo římsových částí s výzdobou florální (listovec aj.) i animální (dvojice delfínů). Kromě nich se v nálezovém konvolutu vyskytlo několik desítek zlomků s reliéfně ztvárněnými erby majitelů sídla, jejichž povrch až 


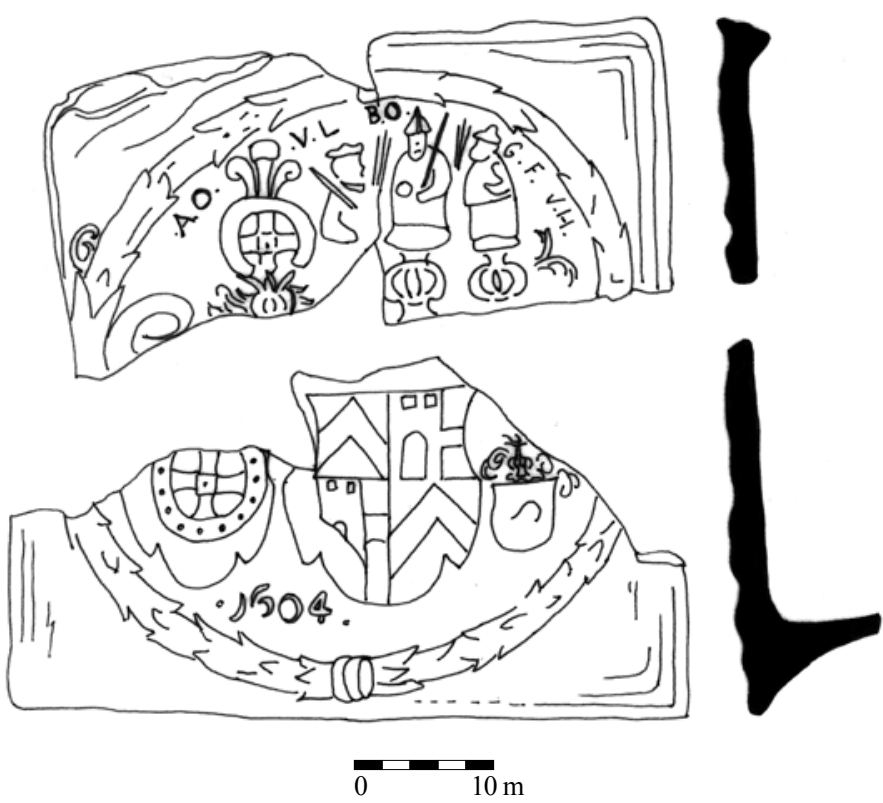

Obr. 5. Radkov-Dubová, Vikštejn, hrad/zámek. Rekonstrukce aliančního znaku Adama Oderského z Lidéřova a Barbary z Herbersteinu. Podle Macků 2007, Tab. 6, překreslila a doplnila M. Tymonová.

Abb. 5. Radkov-Dubová, Vikštejn, Burg/Schloss. Rekonstruktion des Allianzzeichens von Adam Oderský von Liderau und Barbara von Herberstein. Macků 2007, Taf. 6 (nachgezeichnet und ergänzt von M. Tymonová).

na několik režných kousků překrývalo sytě žluté, zelené, tmavě hnědé a polychromní glazování v odstínech žluté, zelené, hnědé a namodralé barvy. Na základě kompletace se podařilo zjistit, že šlo o kachle čtvercového formátu o přibližných rozměrech $180 \times 180 \mathrm{~mm}$, které ve stěnách kamen vytvářely samostatné sestavy, anebo kombinace se zrcadlovými kusy zabudovanými nejspíš v soklové partii. Na žlutě polévaných exemplářích se vyskytly zelené stékavé skvrny poukazující na výrobu $v$ jedné dílenské várce.

Heraldickou výzdobu tvořil alianční znak manželů Oderských s trojicí sdružených znaků a postranními fafrnochy, které obepínal vavř́inový věnec sepnutý nahoře a dole dvojicí prstenců na způsob medailonové kartuše, jaká se běžně užívala na konci 16. a na počátku 17. století (obr. 5; Divileková 2007, 222). Jejich pořadí respektovalo heraldická pravidla aliančního uspořádání, takže erb muže (manžela) byl umístěn vpravo tak, aby se (zrcadlově) přivracel ke znaku manželky, což u Adama Oderského s palečným kolem (o čtyřech loukotích) na štítě i v klenotu s paví kytkou nevyžadovalo nijakých úprav. Nalevo od něj, tedy uprostřed, byl položen čtvrcený štít hraběnky Barbary z Herbersteinu s krokví v prvním a čtvrtém poli a polceným druhým a třetím polem $\mathrm{s}$ věží vpravo a břevnem vlevo. Na štítu byly posazeny tři turnajové přilbice s klenotem v podobě tří mužských postaviček, z nichž prostřední ve vysokém klobouku s žezlem a jablkem stála en face a obě krajní se k ní přivracely; postava vpravo držela trojici liliovitých prutů a vlevo šípy. Jako poslední v řadě vlevo byl ještě třetí, zatím neurčený štítek kosmo dělený oblačným řezem s přilbicí a špatně zachovaným klenotem tvaru listnatého stromu (?). Nad aliančními znaky byly do vnitřního opisu věncového orámování vepsány inskripce v latinské kapitále - vpravo: A[dam]. O[drau]. V[on]. L[iderov]. a vlevo: B[barbara]. O[drau]. G[rafin]. F[rau]. $\mathrm{V}$ [on]. H[erberstein]. Vespod mezi hroty prvních dvou štítů se na jednom rohovém polychromně polévaném kachlovém fragmentu dochoval letopočet 1604, který nejspíše připomíná manželské spojení nositelů výše popsaných rodových erbů. Do tohoto heraldického souboru náleží ještě 


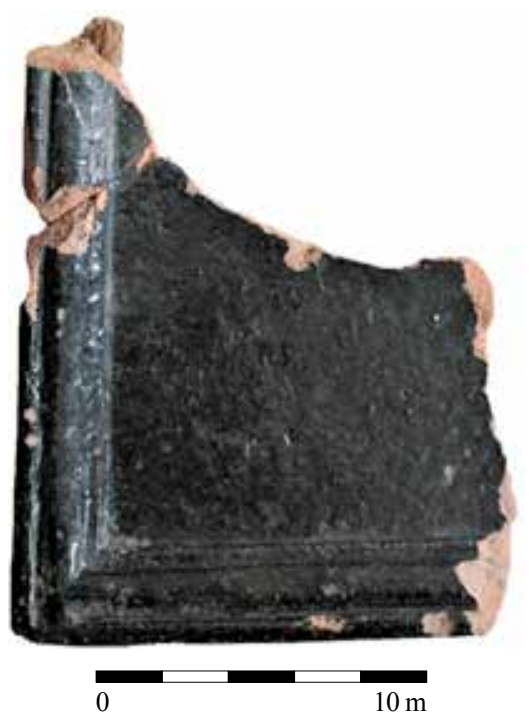

Obr. 6. Radkov-Dubová, Vikštejn, hrad/zámek. Zlomek hnědě glazovaného zrcadlového kachle. Foto M. Tymonová. Abb. 6. Radkov-Dubová, Vikštejn, Burg/Schloss. Fragment einer braunglasierten Spiegelkachel. Foto M. Tymonová.

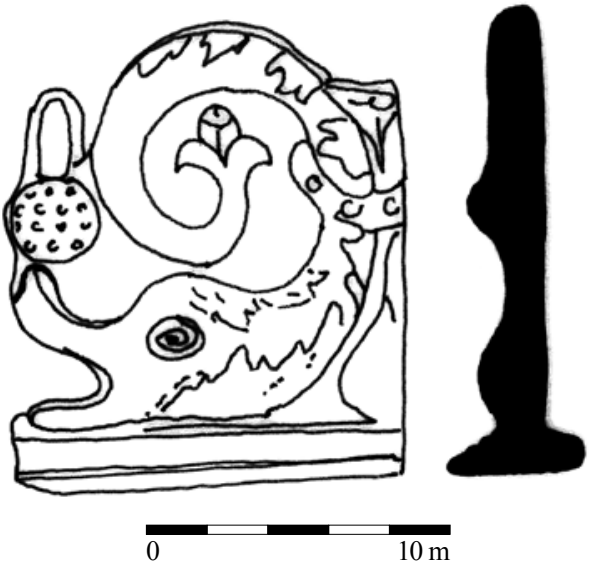

Obr. 8. Opava, Krnovská ulice. Akroterium s delfínem. Podle Krasnokutská 2005, 115, Tab. 23:2.

Abb. 8. Opava, Krnovská-Str. Akroterion mit Delphin. Nach Krasnokutská 2005, 115, Taf. 23:2. další zlomky zachycující pouze dílčí část znaku Barbary z Herbersteinu, identifikovaného na hnědě glazovaných zlomcích. Dochovaný výsek s částí krokve na zjednodušeném štítě a vlevo stojící postavičkou z klenotu herbersteinského znaku s písmeny B[arbara]. O[drau], což by mohlo hypoteticky naznačovat, že se jedná o mladší variantu znaku, kterou hraběnka užívala jako manželka Adama Oderského a pak jako vdova.

Na základě výše uvedené analýzy můžeme vznik kachlů se sdruženými znaky spojit se stavebními úpravami za panství Adama Oderského $\mathrm{z}$ Lidéřova, který nejspíše $\mathrm{v}$ roce 1604 uzavřel sňatek s paní z Herbersteinu, čehož je dokladem sám alianční znak reprezentující spojení v manželském svazku. Jako období relevantní pro vznik matrice či formy připadá rozmezí let 1604-1618/1625, což by $\mathrm{v}$ případě hnědě glazovaných kachlů mohlo být čistě hypoteticky zúženo na léta 16181625 (Pilnáček 1930, 166-167, 201; Šikulová 1973, 87-88, 170, Tab. 62, 1-7; Kouřilová 1975, 22; Schittny 1984; 83-84; Mysliveček 2005, 31; Macků 2007, 37-46, 57-58, Tab. 38-54; Tymonová 2007, 507; 2011, 131-133; Vitanovský 2008, 93, 105, kat. č. 317).

Vedle výše popsaných zlomků s manželskými erby do hnědě glazované sestavy kamen evidentně náležely také zlomky kachlů s hladkým plochým zrcadlem orámovaným vývalkovou lištou (obr. 6) a také další rohové a kordonové součásti včetně akroteria se stylizovanými delfíny ze římsové partie kamen (obr. 7). Jeho analogie mají obdoby v nálezech z Krnovské ulice v Opavě (obr. 8), kde se nacházela hrnčířská dílna, jež tyto kusy pravděpodobně vyrobila (Šikulová 2004, 19-20; Krasnokutská 2004, 59, 106, tab. 26:2; 2005, 32, 65, 115, tab. 23:2; Menoušková 2005, 179, obr. 9; Tymonová 2007, 506; 2009, 35-38; 2014, 161-165). Další nálezy pochází z areálu zámku v polské Toruni, kde se vyskytlo hnědě

polévané akroterium s delfíny adorujícími strom života, datované před rok 1628 (obr. 9; BielecMaciejewska 2008, 143, 147, ryc. 1, 6). Jiný zeleně glazovaný fragment se štíhlými delfínovitými tvory se našel v Panské ulici v Brně, kde byl vročen do rozmezí let 1607-1617 (Holub-Jordánková-Loskotová 2009, 281-282; Jordánková-Loskotová 2010, 30, obr. 10). Římsové exempláře zobrazující delfíny a andílky známe z Javorníka (Tymonová 2011, 104), Muzea Orlických hor v Rychnově nad Kněžnou, hradu Děvína, krakovského Wawelu nebo knížecího paláce v litevském Vilniusu (Strauss 1940, 43, taf. XII, Abb. 1; Kunčevičius 1993, 95, Abb. 129; Pavlík-Vitanovský 2004, 80, 238, 356, kat. č. 520; Divileková 2008, 194-195, obr. 10:6). 


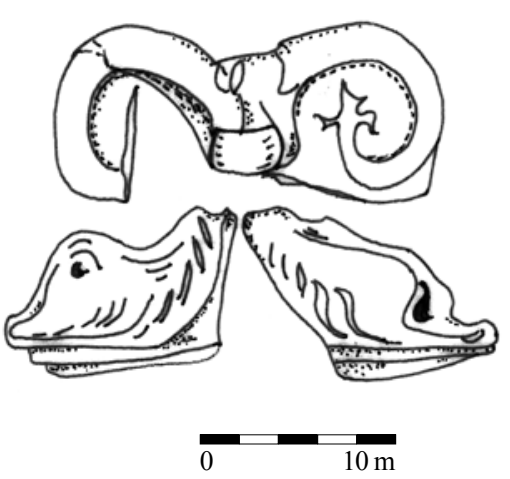

Obr. 7. Radkov-Dubová, Vikštejn, hrad/zámek. Torzo akroteria s delfíny. Kresba M. Tymonová.

Abb. 7. Radkov-Dubová, Vikštejn, Burg/Schloss. Torso eines Akroterions mit Delphinen. Zeichung M. Tymonová.

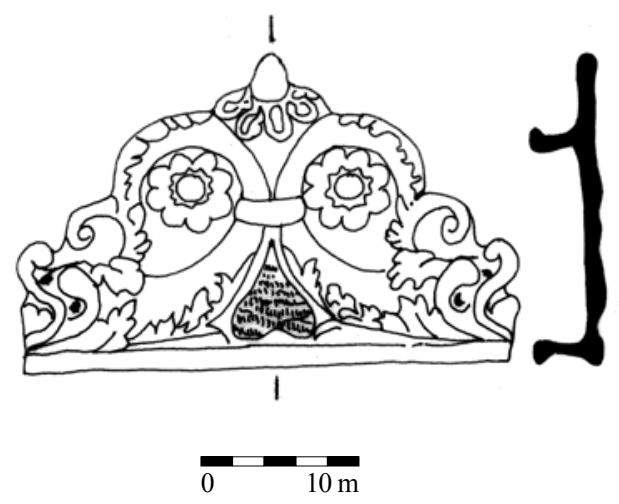

Obr. 9. Toruň, zámek Dybowski. Akroterium s delfíny u stromu života. Pode Bielec-Maciejewska 2008, 151, Ryc. 1. Abb. 9. Thorn, Schloss Dybowski. Akroterion mit Delphinen am Baum des Lebens. Nach Bielec-Maciejewska 2008, 151, Abb. 1.

Ze zmíněné hrnčířské dílny situované $\mathrm{v}$ jaktařské části Opavy pravděpodobně pochází i další hnědě glazované kamna, v nichž byla, podobně jako na Vikštejně, zasazena plochá zrcadla (obr. 10) v kombinaci s heraldicky zdobenými kachlemi. Naznačuje to částečně zachovaný kachlový fragment z Mnišské ulice s aliančním znakem Petra Sedlnického z Choltic na Rosvaldě (Rudolticích) a Barbory Dluhomilové z Bíravy, evidentně ztvárněný týmž autorem (obr. 11). Erby obou manželů s postranními fafrnochy rámoval, stejně jako v př́ípadě vikštejnských exemplářů, vavřínový věnec a kryptogram PS VR, identifikující Petra Sedlnického. Je umístěn v levém horním rohu, číslice $16 \mathrm{v}$ protějším rohu spodním. Jeho erb se zavinutou střelou (tzv. odřivousem) na štítě a klenotem s paví kytkou protnutou šípem byl situován vpravo a hrotem střely se přivracel k erbu Barbory Dluhomilové se třemi lopatami. Datování se podobně jako v předchozím případě opírá o vročení doby sňatku, který manželé uzavřeli v roce 1610 (Pilnáček 1991, 137-138). Tento časový údaj tudíž určuje nejspodnější hranici vzniku formy. Podle materiálu a povrchové úpravy náležely do téže sestavy i další rohové a řádkové kusy ze čtvercových a obdélných zrcadel (obr. 12; Krasnokutská 2004, 69, 109, Tab. 42:3; 73:1; 2005, 38-39, 67, Tab. 36:1, 66:6).

Spojnici mezi výše zmíněnými nalezišti vytváŕí římsové kachle se dvěma andílky, z nichž jeden drží knihu a druhý hraje na píštalu, které se vyskytly ve vikštejnském konvolutu a také v celcích z Mnišské a Krnovské ulice včetně náměstí Republiky (obr. 11; Krasnokutská 2004, 71-72, 110, Tab. 27:1-4, 28:1, 43:1, 47:1, 71:9; 2005, 40-43, 65, 68, 132, Tab. 24, 36:2, 40:1). Další paralely dokládající distribuci kachlového zboží z hrnčířského centra v Krnovské ulici reprezentují kachle se znakem opavského a krnovského knížete Karla z Liechtenštejna († 1627) a jeho syna Eusebia, rozšířené od roku 1622 v kamnech instalovaných v interiérech opavských měštanských domů v ulicích kolem náměstí a také na zámku v Litultovicích nebo Šternberku (Šikulová 2004, 27; Krasnokutská 2004, 109, Tab. 57:1-4, 65:7; 72:10; 2005, 64-65, Tab. 48:3, 49:1, 56:7, 61:5; Tymonová 2007, 506-507, obr. 1; 2011, 133; Vitanovský 2008, 93, 104, kat. č. 313). Uvedené prŕklady naznačují, že kamna sestavená z kachlů s heraldickou symbolikou a zrcadlových exemplářů se v první třetině 17 . století stala velice módními a představovala speciální kamnářské zakázky, které byly vyráběny u příležitosti sňatků př́islušníků aristokratických vrstev. 


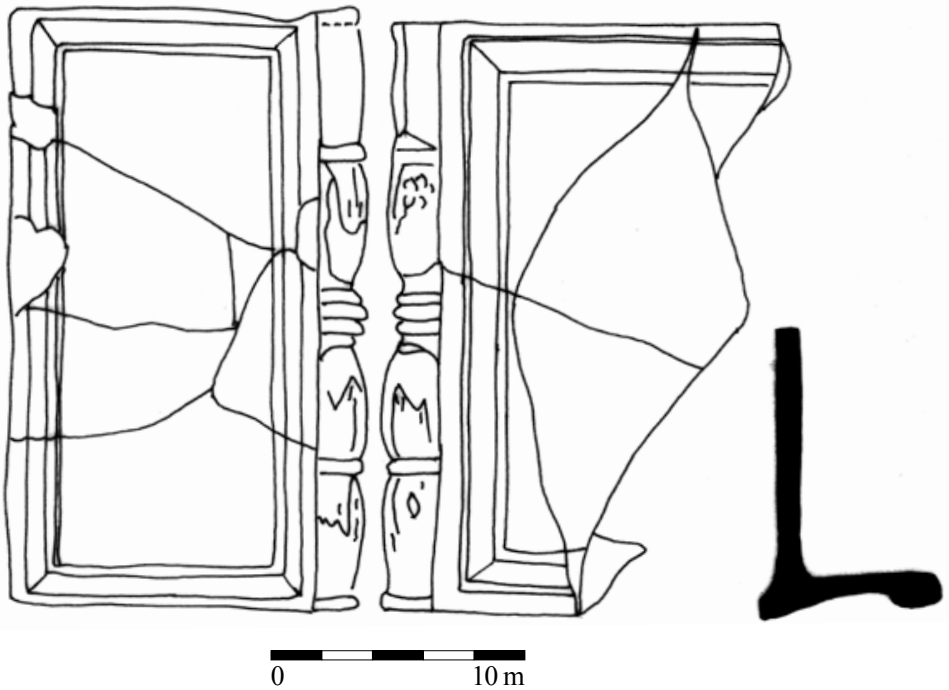

Obr. 10. Opava, Mnišská ulice. Rohový kachel s nárožním sloupkem a obdélným zrcadlem. Podle Krasnokutská 2005, 127, Tab. 35:1.

Abb. 10. Opava, Mnišská-Str. Eckkachel mit Ecksäule und rechteckigem Spiegel. Nach Krasnokutská 2005, 127, Taf. $35: 1$.
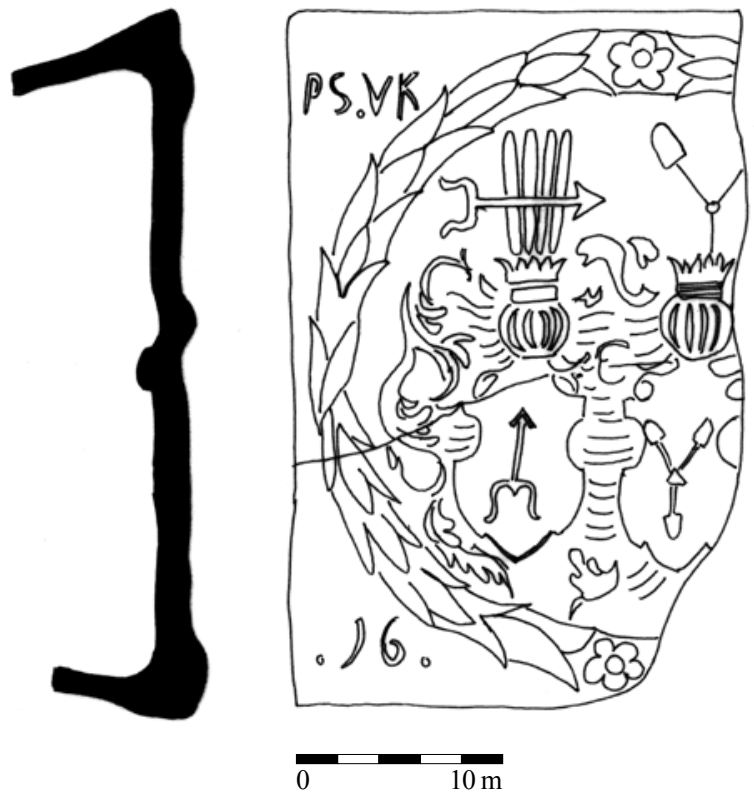

Obr. 11. Opava, Mnišská ulice. Alianční znak s erby Petra Sedlnického z Choltic na Rosvaldě (Rudolticích) a Barbory Dluhomilové z Bíravy. Podle Krasnokutská 2005, 128, Tab. 36:1.

Abb. 11. Opava, Mnišská-Str. Allianzzeichen mit Wappen von Peter Sedlnitzky von Choltitz zu Rosswald und Barbara Dluhomil von Bírava. Nach Krasnokutská 2005, 128, Taf. 36:1. 


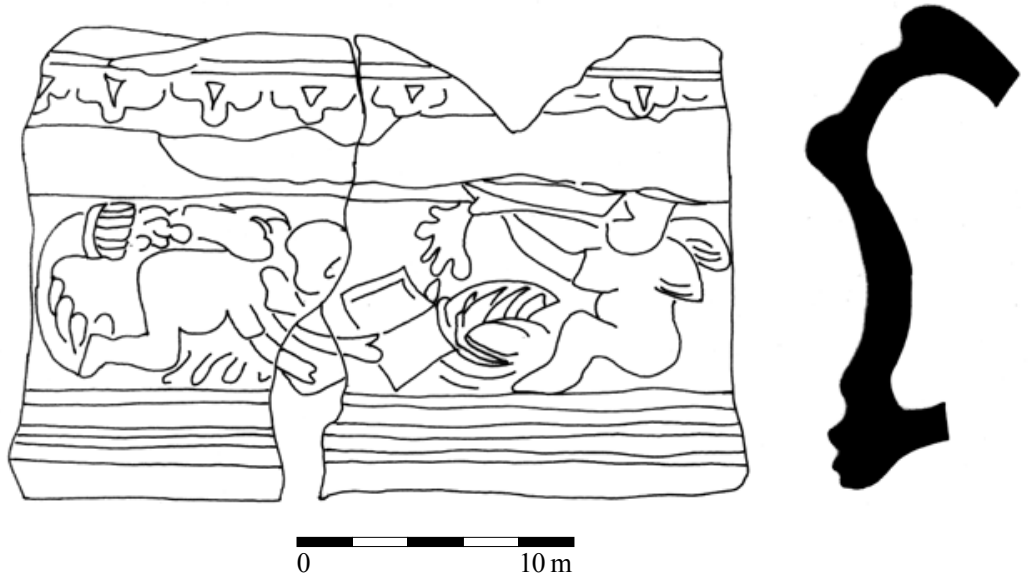

Obr. 12. Opava, Krnovská ulice. Římsový kachel s andílky. Podle Krasnokutská 2005, 116, Tab. $24: 1$. Abb. 12. Opava, Krnovská-Str. Gesimskachel mit Engeln. Nach Krasnokutská 2005, 116, Taf. 24:1.

\section{Závěr}

V konečné rekapitulaci lze konstatovat, že podle toho, co víme, se zrcadlové kachle začaly vyrábět v lokálních hrnčířských dílnách někdy na konci přechodného pozdně gotického období a v počátečních fázích raného novověku. Jejich geneze však př́ímo nesouvisela s novokřtěnskou produkcí, nýbrž jí byla zčásti ovlivněna, a to jednak prostřednictvím některých převzatých výzdobných prvků, které se objevily na plochém zahloubení čelních stěn, a pak hlavně skrze technologické inovace konstrukčního charakteru. Pro datování materiálu z konce 16. a počátku 17. století, kdy se rozšiřily hladké nezdobené kusy, můžeme využít kachlové celky, v nichž se objevují exempláře s heraldickou výzdobou, které bývaly $\mathrm{v}$ kamnových tělesech zabudovány samostatně, anebo v kombinaci se zrcadlově ztvárněnými jedinci. Př́kladem jsou nálezy z hradu Vikštejna a Opavy, jejichž datování do první třetiny 17. století poukazuje na využívání heraldické symboliky ve výzdobě kamen ještě hluboko v raném novověku. Uvedené příklady dokládají, že šlo o speciální zakázky reprezentativního charakteru, realizované v hrnčířské dílně v Krnovské ulici v Opavě, v níž se kromě běžné kuchyňské a stolní keramiky vyrábělo i kamnářské zboží luxusního charakteru.

Příspěvek vznik1 s podporou grantového projektu GA17-13967S Zdroje a šíření vybraných komodit keramické produkce vrcholného a pozdního středověku.

\section{Literatura}

ANSORGE, J.-SCHÄFER, H., 2009: Die Ausgrabungen im Stralsunder Johanniskloster in den Jahren 2006 und 2007 unter besonderer Berücksichtigung der spätgotischen und renaissancezeitlichen Ofenkacheln, Archäologische Berichte aus Mecklenburg-Vorpommern 16, 136-176.

BARTOŠKOVÁ, Š., 2008: Habáni v Dambořicích na Ždánicku, nepubl. rkp. bakalářské práce na KH PF MU v Brně, vedoucí práce doc. PhDr. B. Klíma, CSc.

BIELEC-MCIEJEWSKA, B., 2008: Piece kaflowe z Zamku Dybowskiego w Toruniu (początek XVII wieku), Rocznik Toruński, tom 35, 141-156. 
BRYCH, V., 2004: Kachle doby gotické, renesanční a raně barokní. Výběrový katalog Národního muzea v Praze. Praha.

BRYCH, V.-STEHLÍKOVÁ, D.-ŽEGKLITZ, J., 1990: Pražské kachle doby gotické a renesanční. Katalog výstavy. Praha.

DIVILEKOVÁ, D., 2007: Renesančné kachlice z hradu Devín - Die Renaissance-Ofenkacheln der Burg Devín, Zborník Filozofickej fakulty UK. Musaica XXV, 219-235.

- 2008: Vykurovanie na hrade Devín - Wie auf der Burg Devín (Theben) geheizt wurde, AH 33, $185-198$.

DYMEK, K., 1995: Średinowieczne i renesansowe kafle śłaskie. Wrocław.

FURMANEK, M.-KULPA, S., 2003: Zamek Wodzisławi i jego właściciele. Wodzisław Śłaski.

GOŠ, V.- KAREL, J., 2011: Renesanční kachle ze zámku Janovice u Rýmařova. In: Quod bene notandum Co je třeba poznamenat (Pohanka, J.-Pohanka, V.-Stanzel, V., edd.), 71-91. Bruntál.

HAZLBAUER, Z., 2003: Vývoj stavební podoby a funkce kachlových kamen ve středověku a raném novověku - Entwicklung der Bauform und Funktion von Kachelofen im Mittelalter und in der frühen Neuzeit. In: Svorník 1, 153-168. Praha.

HAZLBAUER, Z.-HLAVÁČEK, Z., 1997: Početný pozdně renesanční kachlový soubor z hradu Rýzmburku, okr. Náchod, ZMHK 23, 123-135.

HLUBEK, L., 2017: Kachle s pěti kruhovými prohlubněmi z areálu města Litovle - Kacheln mit fünf kreisförmigen Vertiefungen aus dem Areal der Stadt Litovel, AH 42, 863-873.

HOFFMANN, C., 2005: “...leth ick den nign Kachelauen maken...”. Renaissancezeitliche Ofenkacheln aus der Hansestadt Stralsund - Eine Auswahl. In: Bemerkungen zur Renaissance in Stralsund. Heft 2 (Brüggemann, S., ed.), 59-66. Stralsund.

HOLL, I., 1993: Renaissance-Öfen. Mittelalterliche Ofenkacheln in Ungarn, Acta Archaeologica Academiae Scientiarum Hungaricae 45, 247-299.

HOLOUBKOVÁ, T., 2013: Gotické a renesanční kachle z hradu Rožnova - Gothic and Renaissance tiles from Rožnov castle, nepubl. rkp. bakalářské práce na Katedře dějin umění FF UP v Olomouci, vedoucí práce Mgr. P. Čehovský, PhDr.

HOLUB, P.-JORDÁNKOVÁ, H.-LOSKOTOVÁ, I., 2009: Early Modern period Brno stove tiles with a mosaic (tapestry) pattern. In: Studies in Post-Medieval Archaeology 3. Post-medieval ceramics. Production, assortment, usage - Novověká keramika. Výroba, sortiment, užití - Neuzeitliche Keramik. Produktion, Sortiment, Verwendung, 273-302. Prague.

HUDEČEK, J. J.-HANÁK, F.-HUDEČEK, P., 2002: Bravantští z Chobřan na Přerovsku a heraldická památka na jejich rod, Sborník státního okresního archivu v Přerově, 29-35.

JORDÁNKOVÁ, H.-LOSKOTOVÁ, I., 2010: Delfíni v renesančním Brně, BMD 23, $26-46$.

KALINOVÁ, A., 2016: Novokřtěnci na Moravě a jejich kulturní odkaz - Anabaptists in Moravia and their cultural legacy, Národopisná revue 4, 271-283.

KOUCKÁ, A., 2015: Keramika a její dílenská, manufakturní a tovární produkce na Moravě od novověku po počátek 20. století - Keramik und ihre Herstellung in Werkstätten, Manufakturen und Fabriken in Mähren von der Neuzeit bis zum Anfang des 20. Jahrhunderts. In: Workshopy ke stř̌edověké a novověké keramice: Panská Lhota 2015 (Měřínský, Z.-Klápště, J., edd.), 46-55. Brno.

KOUŘIL, P.-PRIX, D.-WIHODA, M., 2000: Hrady českého Slezska. Brno - Opava.

KOUŘILOVÁ, D., 1975: Hrad Vikštejn, Vlastivědné listy 1/2, 20-22.

KRASNOKUTSKÁ, T., 2004: Středověké a novověké kamnářství v Opavě na základě nálezů z archeologických výzkumů, nepubl. magisterská dipl. práce na ÚAM FF MU v Brně, vedoucí práce prof. PhDr. Z. Měřínský, CSc.

- 2005: Středověké a novověké kachle z Opavy. Katalog nálezů z archeologických výzkumů. Archaeologiae Regionalis Fontes 8. Olomouc.

KUNCEVIČIUS, A., 1993: Die Kacheln aus dem Palast der Grossfürsten in Vilnius. In: Archäologische Schätze aus Litauen. Begleitband zur gleichnamigen Ausstellung, 82-134. Vilnius - Duisburg - Regensburg.

LANDSFELD, H., 1947: Co vyráběli novokřtěnští keramikové v Podivíně, VVM II, 222-238.

- 1950: Lidové hrnčířství a džbánkařství. Besedy o řemesle džbánkařském, hrnčířském a kamnářském. Praha.

- 1953: Výroba habánské keramiky ve světle vykopávek, Český lid 40, 205-212.

- 1974: Keramická pec v Dambořicích z 15. století, Od hradské cesty. Prameny k dějinám současnosti Žarošic a okolí, 1971-1972, 84-90.

LOSKOTOVÁ, I., 2008: Ornament na kachlích. In: Krása, která hřeje. Výběrový katalog gotických a renesančních kachlů Moravy a Slezska - Schönheit, die wärmt. Gotische und renessainzeitliche Kacheln aus Mähren und Schlesien (Menoušková, D.-Měřínský, Z., edd.), 139-155. Uherské Hradiště. 
MACKŮ, P., 2007: Kachle s heraldickými motivy na Opavsku - Tiles with herladic motives in Opava region, nepubl. rkp. bakalářské práce na FPF SU v Opavě, vedoucí práce PhDr. Vladimír Goš, CSc.

MAJEWSKI, M., 2015: Renesansowe kafle zachodniopomorskie. Studium z historii ogrzewania wnętrz mieszkalnych. Stargard - Szczecin.

MALÍK, P.-PEŠKA, M., 1994: Soubor časně novověké keramiky z Moravského Krumlova - The collection of postmedieval pottery from the Moravský Krumlov Town, SPFFBU E 39, 93-111.

MARTINEK, B.-KRAVAR, Z., 2001: Vítkov. Z historie města. Vítkov.

MENOUŠKOVÁ, D., 2005: Nefigurální renesanční kachle z Dambořic, Slovácko XLVI, 161-181.

MYSLIVEČEK, M., 2005: Velký erbovník. Svazek I. Plzeň.

PAJER, J., 1983: Počátky novověké keramiky ve Strážnici. Strážnice.

- 1989: Habánské keramické středisko ve Strachotíně, Sborník krajského střediska státní památkové péče a ochrany př́rody v Jihomoravském kraji. 30 let KSSPOP v Brně, 190-207.

- 1990: A hoard find of the pottery of the area of the Habaner (Anabaptist) court at Strachotín. In: Studies in Post-Medieval Archaeology 1 (Smetánka, Z.-Žegklitz, J., edd.), 169-202. Praha.

- 1997: Novokřtěnci v Podivíně, Podivín - vlastivědný sborník jihomoravského města, 184-193.

- 1998: Novokřtěnci ve Staré Břeclavi. (K možnostem identifikace novokřtěnských fajánsí podle archeologických nálezů) - Wiedertäufer in Stará Břeclav. (Zu den Identifikationsmöglichkeiten der Wiedertäuferfayencen nach den archäologischen Funden), JM 33, sv. 37, 53-72.

- 1999: Novokř̌̌nci ve Vacenovicích - The Anabaptists in Vacenovice, Slovácko XLI, 31-54.

- 2001: Novokřtěnské fajánse ze Strachotína. Mikulov.

- 2002: Strážnice v pozdní renesanci (Studie o městě a obyvatelích na konci 16. a začátku 17. století). In: Strážnice. Kapitoly z dějin města (Pajer, J. a kol., edd.), 147-190. Strážnice.

- 2006: Nové výzkumy novokřtěneckých fajánsí na Moravě. In: Středověké a novověké zdroje tradiční kultury, 121-139. Brno.

- 2006a: Studie o novokřtěncích. Strážnice.

- 2010: Výroba novokřtěneckých fajánsí na Moravě. Souhrn podle nejnovějších archeologických výzkumů. In: Zaměřeno na stř̌edověk. Zdeňkovi Měřínskému k 60. narozeninám (Přichystalová, R.-Ungerman, Š́, edd.), 496-510. Praha.

- 2011: Novokřtěnecké fajánse z Moravy 1593-1620. Soupis dokladů z institucionálních a privátních sbírek. Strážnice.

- 2015: Nově objevené sídlo novokřtěnců v Čermákovicích (Dvůr Alinkov, k. ú. Horní Kounice, okres Znojmo), Sborník Státního okresního archivu Znojmo, 40-59.

PAVLÍK, Č.-ŠEDO, O., 2006: Soubor kachlů z obce Bulhary u Mikulova, RegioM 2006. Sborník Regionálního muzea v Mikulově, $18-45$.

PAVLÍK, Č.-VITANOVSKÝ, M., 2004: Encyklopedie kachlů v Čechách, na Moravě a ve Slezsku. Ikonografický atlas reliéfů na kachlích gotiky a renesance. Praha.

PILNÁČEK, J., 1930: Staromoravští rodové. Vídeň.

- 1991: Rody starého Slezska. Brno.

POLLA, B., 1970: Stredoveké kachlice z Kežmarku, Východoslovenský pravek 1, 121-133.

PREUSZ, M., 2011: Hmotná kultura raně novověkého měšt’anského domu na př́ikladu hromadného nálezu ze studny domu čp. 55 na Latránu v Českém Krumlově, nepubl. rkp. seminární práce na AÚ FF JČU v Českých Budějovicích, vedoucí práce doc. PhDr. R. Krajíc, CSc.

RIGASOVÁ, M., 2014: Novokřtěnci v Mikulově a okolí. Mikulov.

SACHS, H., 1976: Die Welt des Hans Sachs. 400 Holschnitte des 16 Jahrhunderts. Eine Ausstellung der Stadt Nürnberg Stadtgeschichtliche Museen im Kemenatenbau der Kaiserburg 30. 7. - 3. 10. 1976. Nürnberg.

SCHITTNY, H. R., 1984: Odersky. Die Geschichte einer mährischen Familie. Neustadt an der Aisch.

SEĎOVÁ, M., 2011: Počátky habánského hrnčířství na Moravě se zvláštním zřetelem k její severní části Origins of Haban's pottery in Moravia with a special view to north part, nepubl. rkp. bakalářské práce na Katedře dějin umění FF UP v Olomouci, vedoucí práce PhDr. J. Bláha.

STRAUSS, K., 1940: Kacheln und Ofen der Steiermark. Studien zur Geschichte der Keramik in der Ostmark. Beiträge zur Kunstgeschichte Steiermarks and Kärtens. Graz.

SUCHNOVÁ, J., 2012: Lipnický kachlový poklad - akcese, tezaurace, prezentace, nepubl. magisterská dipl. práce na ÚAM FF MU v Brně, vedoucí práce prof. PhDr. J. Dolák.

ŠEBELA, L.-VANĚK, J., 1985: Hromadný nález ze studny v areálu bývalého bratrského sboru v Ivančicích. Přelom 16. a 17. století - Massenfunde aus dem Brunnen im Areal der ehemaligen Brüdergemeinde der Böhmischen Brüder in Ivančice (Wende vom 16. Jahrhundert zum 17. Jahrhundert). Ivančice.

ŠIKULOVÁ, V., 1973: Nálezy z hradu Vikštejna, obec Radkov-Dubová (okr. Opava), PV 1972, 87-88. Brno. 
- 2004: Habánské umyvadlo Jana Jiř́ho Krnovského nalezené v Opavě. In: Opava. Sborník k dějinám města 4, 19-28. Opava.

TYMONOVÁ, M., 2007: Kachle s lichtenštejnskými znaky ve sbírce Slezského zemského muzea - Kacheln mit liechtensteinischen Wappen in der Sammlung der Schlesischen Landesmuseums, AH 32, 501-510.

- 2009: Středověké reliéfní kachle jako pramen hmotné kultury (Slezsko) - Mittelalterliche Reliefkacheln als Quelle der Sachkultur (Schlesien), AH 34, 209-223.

- 2011: Gotické a renesanční kachle ze slezských hradů - Gothic and Renaissance Tiles from Silesian Castles, rkp. nepubl. disertační práce na ÚAM FF MU, Brno, díl I.-III., vedoucí práce doc. PhDr. P. Kouřil, CSc.

- 2014: Výroba kamnářské keramiky v českých zemích a dílna v Opavě - Belege für die Herstellung von Ofenkeramik in den Ländern Böhmens und eine Werkstatt in Opava, AH 39, 155-175.

- 2015: Medailonové kachle z Javorníka - Die Medaillonkacheln aus Javorník, AH 40, 941-959.

- 2016: Kachlové soubory z Frýdku - Die Kachelkollektionen aus Frýdek, AH 41, 415-435.

VITANOVSKÝ, M., 2008: Heraldické motivy. In: Krása, která hřeje. Výběrový katalog gotických a renesančních kachlů Moravy a Slezska - Schönheit, die wärmt. Gotische und renaissancezeitliche Kacheln aus Mähren und Schlesien (Menoušková, D.-Měřínský, Z., edd.), 90-115. Uherské Hradiště.

ZAHNÁŠ, P., 1981: Kdo byl vikštejnský pán Mikuláš Bravantský z Chohřan, Zpravodaj ostravské pobočky Genealogické a heraldické společnosti v Praze při Domu kultury pracujících Vítkovic v Ostravě III, č. 9 , 2-6.

ZUKAL, J., 1916: Slezské konfiskace 1620-1630. Pokutování povstalé šlechty v Krnovsku, Opavsku a Osoblažsku po bitvě bělohorské a vpádu Mansfeldově. Opava.

ŻEMIGAŁA, M., 1987: Ogrzewanie piecowe na zamku w Bolesławcu nad Prosą w XIV-XVII. w. Wrocław Warszawa - Kraków - Łódź.

\section{Zusammenfassung}

\section{Ein Beitrag zur Datierung von Spiegelkacheln}

Ofenkeramik mit spiegelförmig vertiefter Mittelfläche, die an gotische Nischenformen erinnern, traten in der Kachelproduktion am Ende der Spätgotik und zu Beginn der Renaissance auf. Davon zeugen die Ikonographie von Innenräumen mit Öfen aus der Zeit vor Mitte des 16. Jahrhunderts und die Kacheln mit archaischen halbzylinderförmigen Hälsen aus Frýdek sowie aus Bulhary bei Mikulov aus der Zeit um 1500 (Abb. 1.). Neben diesen rechteckigen Formaten begann man im 16. Jahrhundert auch damit, quadratische Formen mit kegelförmigem Hals herzustellen, die nach der Jahrhundertmitte von Rahmenhälsen abgelöst wurden. Funde kennen wir von Burgen (Frýdek, Rožnov, Rýzmburk, Lipnice, Kežmarok, Bolesławiec nad Prosną, Budin bzw. Köszeg) und auch aus Städten (Oppeln, Stettin, Stargard, Kamień Pomorski, Staré Drawsko, Dobra oder Bierzwnik).

In den Ländern Böhmens kamen Spiegel außer in Prag auch in Opava vor, wo sie von T. Krasnokutská in zwei Grundtypen unterteilt wurden - in einen älteren aus der zweiten Hälfte des 16. Jahrhunderts in quadratischer (Abb. 2; Unterer Marktplatz und Platz der Republik, die Straßen Kolářská, Krnovská und Pekařská) oder in rechteckiger (die Straßen Beethovenova oder Krnovská) Ausführung, und in einen jüngeren Typ vom Ende des 16. und Anfang des 17. Jahrhunderts mit glattem, unverziertem Blatt, das mit einer grünen Glasur und ab Beginn des darauffolgenden Jahrhunderts auch mit einer dunkelbraunen Glasur (Straßen Mnišská und Pekařská) überzogen war. Unverzierte Formen aus der zweiten Hälfte des 16. Jahrhunderts wurden auch in Hradec Králové und zu Beginn des 17. Jahrhunderts in Moravský Krumlov (Abb. 3) entdeckt.

Im 16. Jahrhundert wurden Verzierung und Bauweise von Ofenkeramik auch von der Produktion der Wiedertäufer (Habaner) beeinflusst, die geometrische pflanzliche Motive aus religiösen Gründen bevorzugten. Dies wird durch das Kachelmaterial aus Opava belegt, von wo aus die Ofenkeramik im nahegelegenen Vikštejn vertrieben wurde (Abb. 4), wo man Fragmente aus mehreren, farblich unterschiedlichen Renaissanceöfen fand. Deren Datierung in die Jahre 16041618/1625, ggf. 1618-1625 (?), stützt sich auf eine Analyse der heraldischen Verzierung mit dem 
Allianzzeichen von Adam Oderský von Liderau und Barbara von Herberstein (Abb. 5). In einer braun glasierten Zusammensetzung wurde neben Spiegelkacheln auch ein Akroterion mit Delphinen eingefügt (Abb. 6, 7), die u.a. Analogien in der Krnovská-Straße in Opava (Abb. 8), in der polnischen Stadt Thorn (Abb. 9) und in der Panská-Straße in Brünn haben.

In der Mnišská-Straße wurden noch weitere braunglasierte Öfen mit Spiegeln (Abb. 10) und dem Allianzzeichen mit den Wappen von Petr Sedlnirzky von Choltitz zu Rosswald und von Barbara Dluhomil von Bírava (Abb. 11) entdeckt.

Hergestellt wurden sie ebenfalls nach 1610 in Opava in der Werkstatt in der Krnovská-Straße, vergleichbar mit den mit Engeln versehenen Gesimskacheln (Abb. 12), deren Torsos auf Vikštejn gefunden wurden und die aus Werkstätten der Mnišská-Straße und vom Platz der Republik stammen. Das gleiche gilt auch für Kacheln mit dem Wappen von Karl von Liechtenstein und dem Wappen seines Sohnes Eusebius, die man nach 1622 herzustellen begann.

Öfen, die aus Spiegelkacheln und aus heraldisch verzierten Kacheln bestanden kamen im ersten Drittel des 17. Jahrhunderts sehr in Mode. Bei ihnen handelte es sich um spezielle Auftragsarbeiten, die anlässlich Hochzeiten von Angehörigen der Adelsschichten hergestellt worden waren.

PhDr. et PhDr. Markéta Tymonová, Ph.D., Ústav archeologie Filozoficko-př́rodovědecké fakulty Slezské univerzity v Opavě, Bezručovo náměstí 13, 74601 Opava, Česká republika, marketa.tymonova@fpf.slu.cz 
